\title{
DESIGN AND MANUFACTURE OF BAMBOO HANDICRAFT DRYER MACHINE BASED ON LPG GAS
}

\author{
Muhammad Agus Saparudin a,1,*, Rizal Justian Setiawan ${ }^{\mathrm{a}, 2}$, Eko Budi a,3, Aji Puspito ${ }^{\mathrm{a}, 4}$, Imam \\ Fauzi a,5 \\ ${ }^{a}$ Universitas Negeri Yogyakarta, Jl. Colombo Yogyakarta No.1, Kabupaten Sleman, Daerah Istimewa Yogyakarta 55281, Indonesia \\ ${ }^{1}$ magussaparudin@gmail.com; ${ }^{2}$ rizaljustians@ gmail.com; ${ }^{3}$ ekobudis@gmail.com; ${ }^{4}$ ajipuspito@gmail.com; ${ }^{5}$ imamfauzi.job@gmail.com
}

ARTICLE INFO

Article history

Received : June 30, 2021

Revised : July 10, 2021

Accepted : August 09, 2021

\section{Keywords}

Bamboo

Dryer

Handicraft

LPG

\begin{abstract}
The bamboo plant is one of Indonesia's natural resources. People use bamboo to make household furniture, fences, frames, and handicrafts. The bamboo plant is a special commodity that can be used as various handicraft products in DIY, precisely in the Brajan area, Sleman Regency. Based on observations conducted on one of the bamboo craftsmen in the Brajan area, bamboo handicraft is in great demand because they have a unique and ethnic appearance. Still, the production process is quite complicated and takes a long time. According to the literature, this is due to bamboo plants are classified as herbaceous plants, namely plants with watery or wet stems. So far, the method used is drying bamboo handicrafts under the hot sun and using a dryer that can only be used for one type of handicraft. This method is not optimal and not effective for producing bamboo handicrafts. Therefore, it is necessary to apply appropriate technology to optimize the production of bamboo crafts; the solution is to manufacture bamboo dryers to facilitate bamboo handicraft producers in the bamboo drying process. In general, the appearance of this tool resembles a cupboard. This tool has a size of $1200 \times 800 \times 1800 \mathrm{~mm}$ with three chambers. This tool works by utilizing the heat from the LPG gas stove. As a temperature controller, this tool is equipped with a blower that has been programmed with Arduino Uno and functions to stabilize the temperature if the heat generated exceeds the maximum limit. The dryer machine can dry bamboo handicrafts to a water content of $2.5 \%$ in just 40 minutes, very efficient compared to conventional methods. This tool can facilitate and optimize the production of bamboo handicrafts in the Brajan area, Sleman, Special Region of Yogyakarta.
\end{abstract}

This is an open-access article under the CC-BY-SA license.

\section{Introduction}

The Special Region Yogyakarta is one of the provinces in Indonesia which is located in the south of the southern part of Java Island and with several provinces in Central Java, namely in the north with Magelang Regency, in the south with the Indonesian Ocean, in the east with Klaten Regency and in the west with Purworejo Regency. Astronomically it locates between $7^{\circ} 33^{\prime} 8^{\circ} 12^{\prime}$ South Latitude and $110^{\circ} 00^{\prime}-110^{\circ} 50^{\prime}$ East Longitude. Yogyakarta, a Student City, and a Cultural City, has an area of 3,185.80 km2 and consists of 1 city and four regencies. According to the population census, the Special Region of Yogyakarta has a population of 3,452,390 and has a population density of 1,084 people per $\mathrm{km}^{2}$ [1]. As a cultural city, Yogyakarta has more than 75,000 craftsmen, bamboo craftsmen in Brajan Hamlet, Sleman Regency. 
The bamboo handicraft is the art of knitting and usually uses materials from bamboo, rattan, leaves that have fiber and can be thinned, such as water hyacinth, palm leaves, pandan leaves, etc., as well as plastic. Bamboo handicrafts are widely used as tools for daily household needs. The stages of making bamboo crafts are as follows: (1) selection of bamboo; (2) nuisance and cutting of bamboo; (3) removing the skin and cutting bamboo or making bamboo bars; (4) formation according to the model (enrichment); (5) coloring and curing; (6) drying; and (7) packaging. Bamboo material for making handicrafts is usually apus bamboo. This bamboo is chosen due to it is still wet, straight, and has long strands.

The bamboo drying process is essential in producing good handicraft products. Drying is a postharvest process commonly conducted on various agricultural products to reduce the water content to a safe level for storage or other processes [2]. In general, drying bamboo handicrafts in the Brajan area is still traditional, namely drying in direct sunlight. This method is easy and inexpensive. However, traditionally drying bamboo handicrafts will be faced with various obstacles, including: (1) it takes two days to reduce the water content to $12-14 \%$, (2) the drying process is not standard so that it can change the color of the bamboo to fade (3) depending on the weather and, (4) requires intensive labor. The many problems faced have hampered the production process of bamboo handicrafts in Brajan Hamlet. For this reason, other methods are needed so that craft productivity is not hindered.

A dryer machine is an alternative solution for drying bamboo handicraft products if sun drying cannot be done. The drying technique is done by lowering the relative humidity of the drying air by heating the drying chamber to a temperature of $50^{\circ} \mathrm{C}$. The drying process is conducted by making the room tightly closed, then placing a heater in the room. The hot air generated by the heater will be blown into the room with the help of a blower. The heating process mentioned above uses the principle of convection heating. The convection process is blowing the air on the heating element [3]. The air absorbs heat and then spreads the hot air into the room. This bamboo handicraft dryer uses a two burners stove as heating and uses a 150-watt two-inch blower to blow hot air housed in the heating box. Warm air will circulate in the room, raising the temperature to a specific temperature that can be monitored through a thermometer and adjusting the blower flame using the LM 35 sensor and Arduino Uno. This machine consists of several essential components: the engine frame, engine cover, blower, Thermo control, and door.

With this tool, it is expected to increase productivity and added value because the drying process no longer depends on the weather, and artisans can adjust the dryness level needed to produce excellent and high-quality handicraft products.

\section{Literature review}

\subsection{Drying System}

Drying is the application of heating through normal conditions, so it can remove most of the water in a material by evaporation. The water removal in a material by drying has a different operating unit than dehydration. The air contained in the drying process functions as a heat provider to the material, causing the evaporation of water. Another function of philosophy is to transport moisture released by the dried material. The drying speed will increase if the air velocity is increased. When the final Water Content begins to reach its equilibrium, it will also increase the drying time or, in other words, faster [4].

\subsection{Arduino}

Arduino is an open-source physical computing platform. First, it is necessary to understand that the word "platform" here is the right choice of words. Arduino is not just a development tool, but it is a combination of sophisticated hardware, programming language, and Integrated Development Environment (IDE) [5]. 


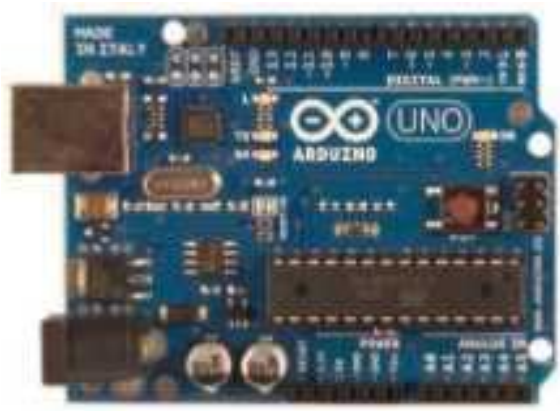

\subsection{LM 35 Sensor}

Fig. 1. Arduino Uno

LM35 is an accurate temperature sensor where the output voltage is directly proportional to the temperature in degrees Celsius by $10 \mathrm{mV} /{ }^{\circ} \mathrm{C}$. This sensor requires external calibration to produce an accuracy of $0.25^{\circ} \mathrm{C}$ at room temperature. While the ability of this sensor to measure temperature lies in the range of $-55^{\circ}-150^{\circ} \mathrm{C}$ with an output voltage between $-1 \mathrm{Vdc}$ to $+6 \mathrm{Vdc}$. The negative voltage sensor output shows a negative temperature [6].

\section{Method}

This research R\&D (Research \& Development) is a research method used to make certain products and test the product's effectiveness [7]. This research will produce a bamboo handicraft dryer product, how to use the product, and the results of bamboo handicraft dryer research. The stages of this research were conducted according to the type of R\&D (Research and Development), which was modified in such a way as to suit the needs of the researcher. There are eight stages in this research, such as problem identification, collecting data, product design, product manufacturing, product validation, product revision, field testing, research data processing.

\subsection{Problem Identification}

Problem identification was conducted by field observation by visiting and interviewing craftsmen in the Brajan area and asking about the problems being faced during the process of making bamboo handicrafts.

\subsection{Collecting Data}

Data collection was conducted by collecting the results of research studies regarding the drying conditions of bamboo handicrafts in Brajan Area, Sleman, Yogyakarta.

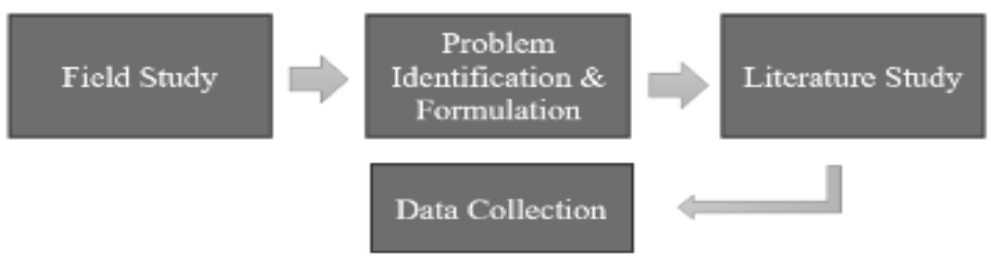

Fig. 2. Data Collection Stage

\subsection{Product Design}

The hardware design of the tool was created using the Solidworks 2018 software. The design of this tool is based on the results of field observations and data collection. In the planning and the explanation section of the product design, research is conducted regarding what design is appropriate for this project by looking for references to similar research and field observation; this serves to determine machine specifications. Furthermore, in the developing product concept section, a design is created in sketch form. In the area of developing product structure, the machine framework in the form of an initial layout is started. After that, we determine the design of the product by creating a product simulation using the application and creating working drawings. And finally, in the product document section, the results of this design stage are details in the form of product design which include detailed machine drawings (2D \& 3D), component lists, material 
specifications, operating systems, tolerances, and other documents in a single unit. The flowchart of the product design can be seen in Fig. 3.

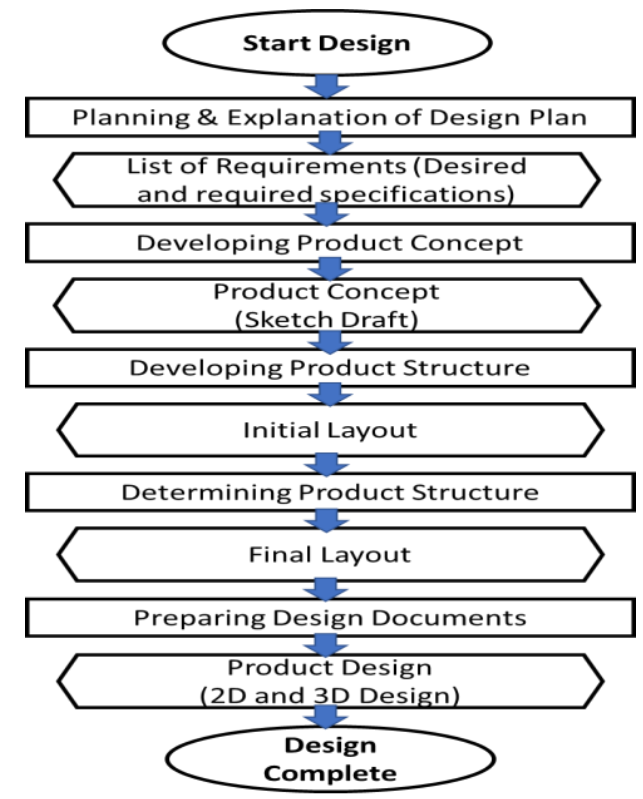

Fig. 3. Product Design Stages

\subsection{Product Manufacturing}

Product manufacture has five steps, which are understanding 2D \& 3D designs or working drawings of tools, surveying and materials selecting, processes manufacturing, assembling, and product finishing. The tools and materials used in this research adjust to the needs by considering the design of the working drawing and the expected output result.

\subsection{Product Validation}

Product validation is carried out by product testing, which includes tool functionality and tool durability. Testing the functionality of the tool is conducted by operating the machine according to its function. This test aims to determine whether the existing components are functioning correctly. To test the durability of the tool, then what is done is to provide maximum load. The test time was carried out for 30 minutes. This test aims to determine the ability of the tool to withstand the full load.

\subsection{Product Revision}

Product revisions are conducted if the test is not as expected. This is done by resetting the controller set on the device with the improvement of the LM35 sensor.

\subsection{Field Testing}

Field testing is conducted by operating the machine in actual conditions that exist in the community. Then compare the drying process using a device with a conventional drying process using sunlight.

\subsection{Research Data Processing}

Data collection was conducted to obtain the information needed in order to achieve the research objectives. The objectives are expressed in the form of test results data which are answers to research questions. The data was collected by a predetermined sample. The sample consists of a set of units of analysis as research targets. There are two ways to obtain this data, namely the method of obtaining Samples and measuring the water content of bamboo handicrafts.

\subsubsection{Method of Getting a sample}

In this experiment, we focused on testing bamboo handicrafts. The following is a sampling procedure for drying bamboo handicrafts using a dryer machine. 
a) Prepare bamboo handicraft products that are ready to be dried. Then, we prepare 30 bamboo handicrafts.

b) Put the craft into the drying tube, and take the sample in 30 minutes.

c) Separate ten bamboo handicrafts in each drying room to be dried using a bamboo handicraft dryer.

d) Turn on the dryer by plugging the power cord plug into the power source/socket, then turn on the controller and press.

e) Wait a while, and the blower automatically starts working until it reaches a temperature of $50^{\circ} \mathrm{C}$.

f) Automatically the blower will continue to rotate to equalize the temperature, and if the temperature is below $50^{\circ} \mathrm{C}$, the blower will turn off by itself.

g) Wait until the craft is dry and take a sample of drying crafts every 10 minutes for three crafts, and named according to the drying time.

h) After reaching 40 minutes, we get four drying samples, end sampling, and press the OFF button on the controller. Then take out the bamboo handicraft in the machine.

\subsubsection{Measuring the Water Content of Bamboo Handicraft}

Furthermore, to observe and determine the decrease in water content in the bamboo handicraft samples, a secondary method was used, namely by using a wood moisture meter Merlin type WS25. Measurement of the water content of the sample was repeated two times every 10 minutes with a tolerance difference of $0.2 \%$. This process is carried out at the Laboratory of the Seed Supervision and Certification Center Agriculture (BPSBP) Department of Agriculture DIY. The data analysis process was conducted by looking for the relationship between Water Content and drying duration.

\section{Results and Discussion}

\subsection{Product Design and Manufacturing}

In creating a machine, design and working drawing are very important things due to; in addition to having clear information about the shape or design and size of the components to be made, they must also have clear information about the signs of the process. On the design in Fig. 4, the tool has several parts, such as a blower, an air chimney, a drying room, LPG gas, and a stove room.

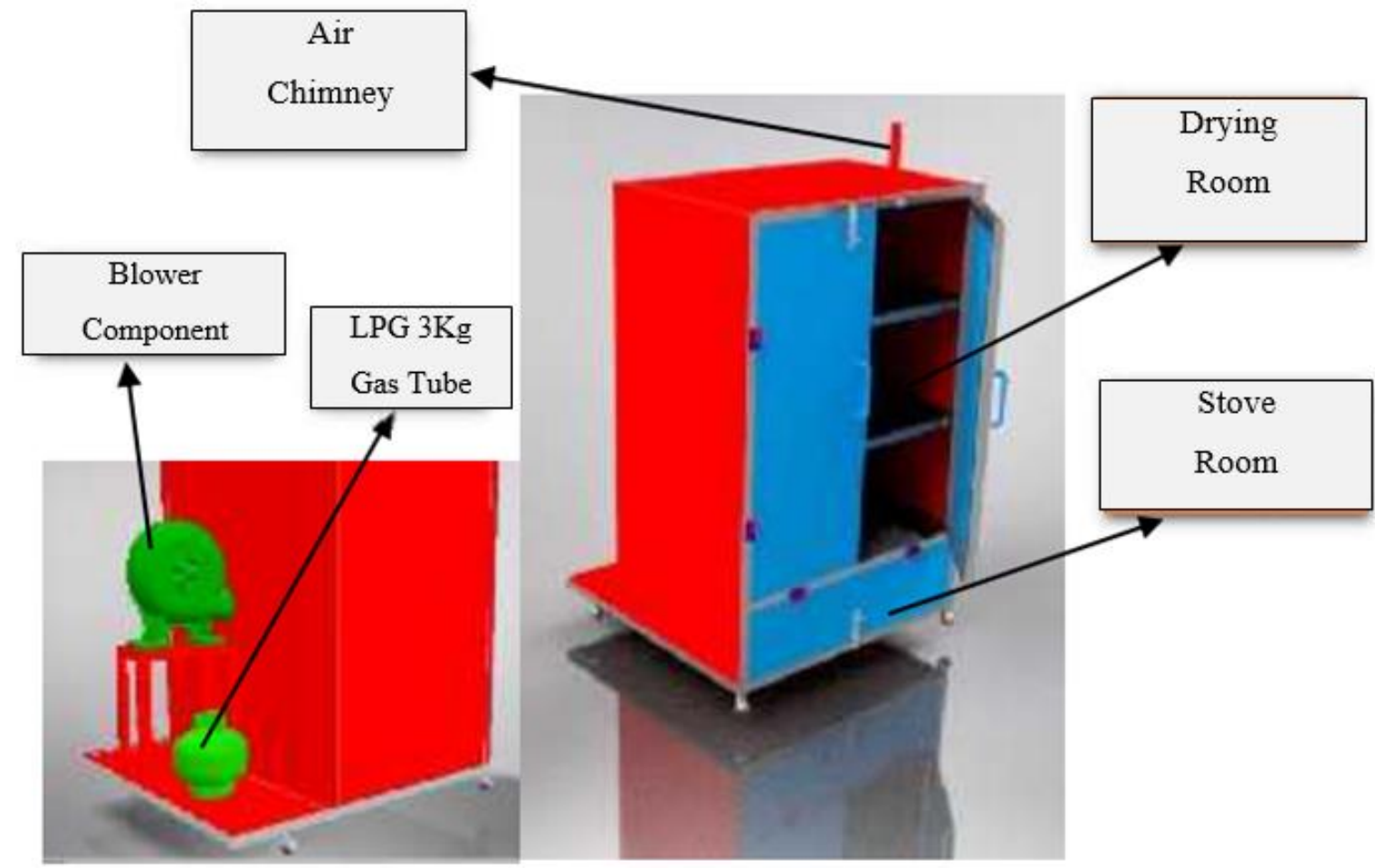

Fig. 4. Product Design 
The blower on the device functions to circulate air and distribute the heat in the drying room. When the heat in the drying room reaches $60^{\circ} \mathrm{C}$, the blower will turn on, controlled by the controller, then when the indoor temperature is $<50^{\circ} \mathrm{C}$, the blower will turn off. Furthermore, the Air chimney functions as an exhaust channel for hot air in the drying room so that evaporation does not occur in the room and so that hot air can circulate. The drying room serves as a place for crafts during the drying process. The height of each partition is $50 \mathrm{~cm}$, and the width is $80 \mathrm{~cm}$, so this tool can be used to dry handicrafts that require a large space. The last one is a two burners gas stove, and the fuel is $3 \mathrm{~kg}$ LPG gas, which functions as a heater.

When the design is complete, the next step is to survey the required materials to the market to match the design specifications. If the price is deemed appropriate, then the material is purchased.

After the materials and tools are ready, they will have to proceed to the tool manufacturing process. In the first stage of manufacturing this tool, namely making a tool frame to determine the size of the dryer room, stove room, and blower holder. The second stage, namely the process of cutting the plate as the cover of the dryer machine. The cover of this machine consists of several covers, namely side covers (right and left), top, bottom, seat, and cabinet doors and stoves. The third working stage is the caulking process. The caulking process serves to flatten the parts that are loose and exposed to welding and grinding marks. So that the results are neat and even during the painting process. The fourth stage is the painting process. This painting process begins with the provision of basic paint in the form of a Poxy so that the surface of the tool is closed from the pores of the surface of the tool that is open due to the working process. After the basic paint is finished, then paint it according to the color chosen and use a spray gun and compressor for painting so that the results are more evenly distributed.

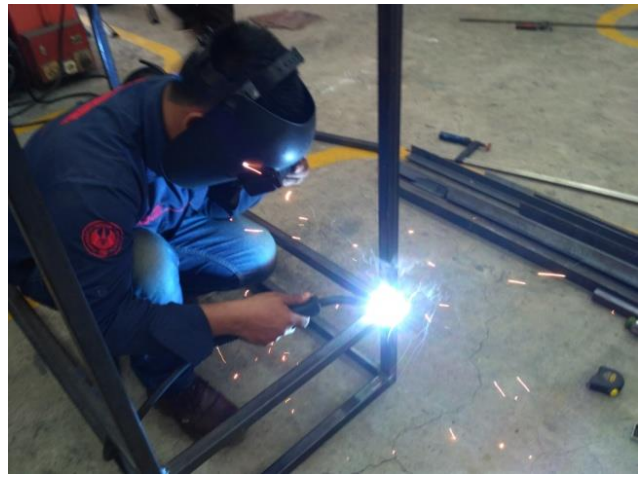

Fig. 5. Manufacture Process

After the painting process is complete, then we conducted the tool assembly process. The assembly process begins with the installation of the blower and controller. Then install the LM 35 sensor at the bottom of the drying room and attach the cable for the electrical system. After the blower and controller are complete, insert the gas stove into the stove room and place the LPG gas on the gasholder, which is behind the cupboard. When the assembly process is complete, test all the mechanisms that have been made so that the grain drying process goes well.

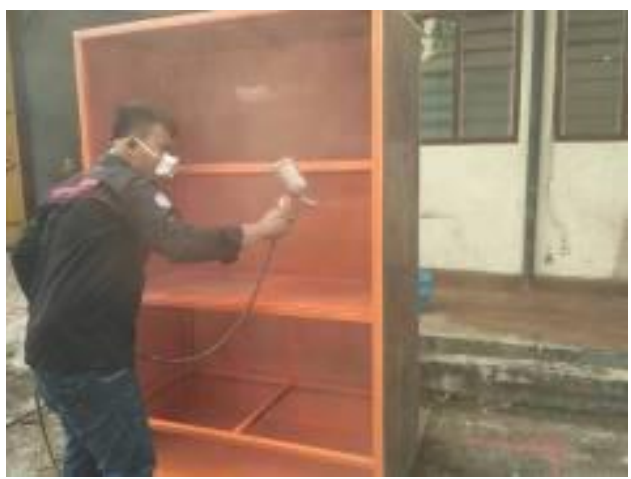

Fig. 6. Finishing Process 
When the manufacturing process is complete, machine testing will be carried out to ensure that the machine is really functioning properly. Bamboo handicraft dryer Machine is a dryer with a batch dryer method. At the same time, the drying system is an indirect dryer.

\subsection{Effectiveness of Bamboo Handicraft Dryer Machine}

This research was conducted using a qualitative analysis technique by comparing the condition of bamboo handicrafts that were dried with a dryer machine and the results of measuring their water content.

The craft samples used in each experiment were 30 pieces. The drying temperature using sunlight is uncertain, which is in the range of $25^{\circ} \mathrm{C}-35^{\circ} \mathrm{C}$. Conventional drying is carried out at 09.00-13.00 WIB, and after being tested using a Wood Moisture Meter, it is still around 5.8\%. While the handicrafts are dried using a bamboo handicraft dryer machine, as many as 30 pieces with the division of each partition ten pieces and a temperature setting of $50^{\circ} \mathrm{C}$. The temperature difference in each partition is $2^{\circ} \mathrm{C}$.

This drying temperature is chosen, so the drying is faster but does not damage the quality of the bamboo craft. One sample was taken from each partition, top, middle, and bottom, every 10 minutes to measure the Water Content using a Wood Moisture Meter. The test results show that there is a significant decrease in water content every minute. Based on the measurement results, the water content of the initial bamboo handicraft before going through the drying process was $17.1 \%$. After drying using a bamboo craft dryer for 10 minutes, the water content of bamboo crafts dropped drastically to $13.6 \%$ for the upper partition, $13.4 \%$ for the middle partition, and $13.1 \%$ for the lower partition. Then there is a gradual decrease in the water content of bamboo handicrafts as the duration of drying using a dryer increases until an average Water Content of $2.5 \%$ is obtained.

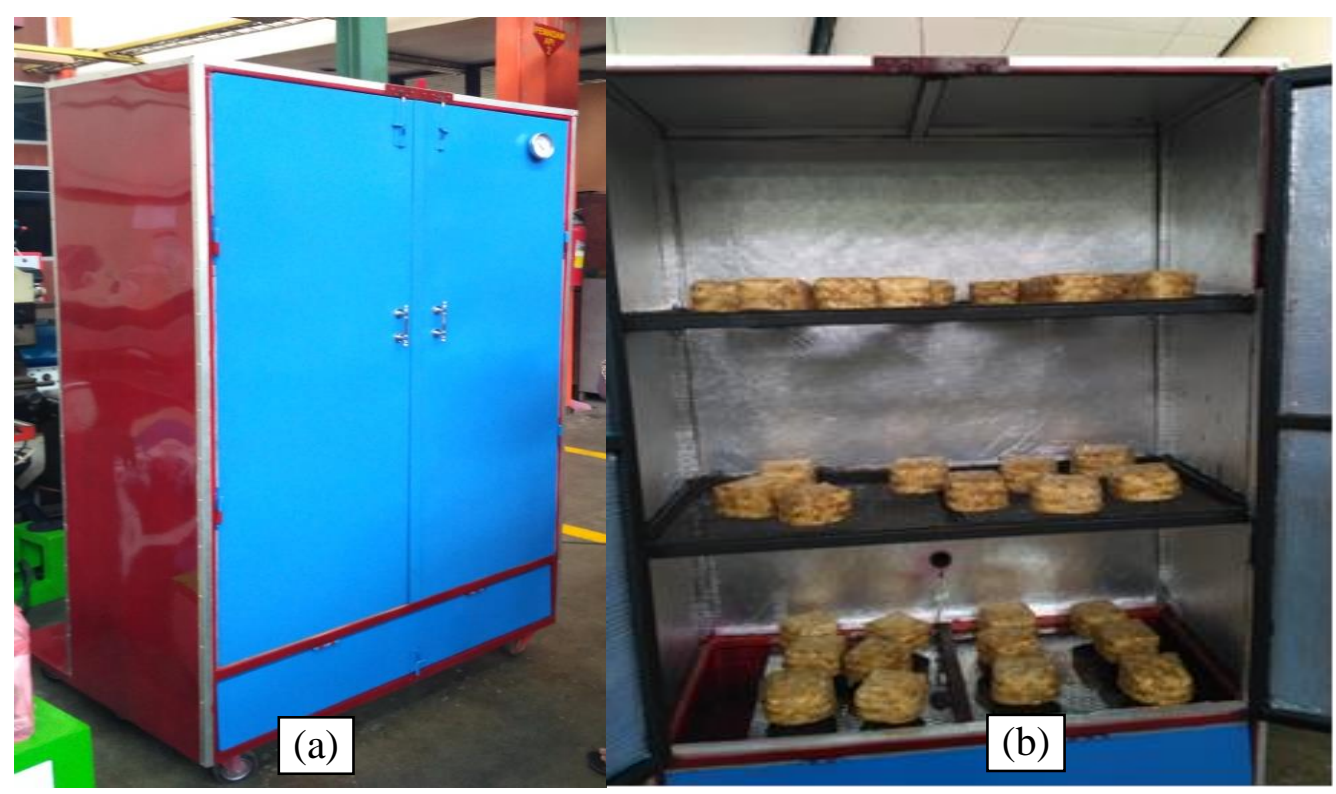

Fig. 7. (a) Outdoor View (b) Indoor View

Based on research, we received data by using a bamboo handicraft dryer to achieve dry bamboo crafts with a Water Content of $2,5 \%$ only takes about 40 minutes at an average temperature of $50^{\circ} \mathrm{C}$. In addition, the data analysis process was conducted by looking for the correlation between Water Content and drying duration using a bamboo handicraft dryer compared to conventional drying processes using sunlight. Measurement of Water Content in Bamboo handicraft samples using a Wood Moisture Meter. The results of the comparison can be seen in table 1. 
Table 1. Measurement of Water Content in Bamboo Handicraft Samples

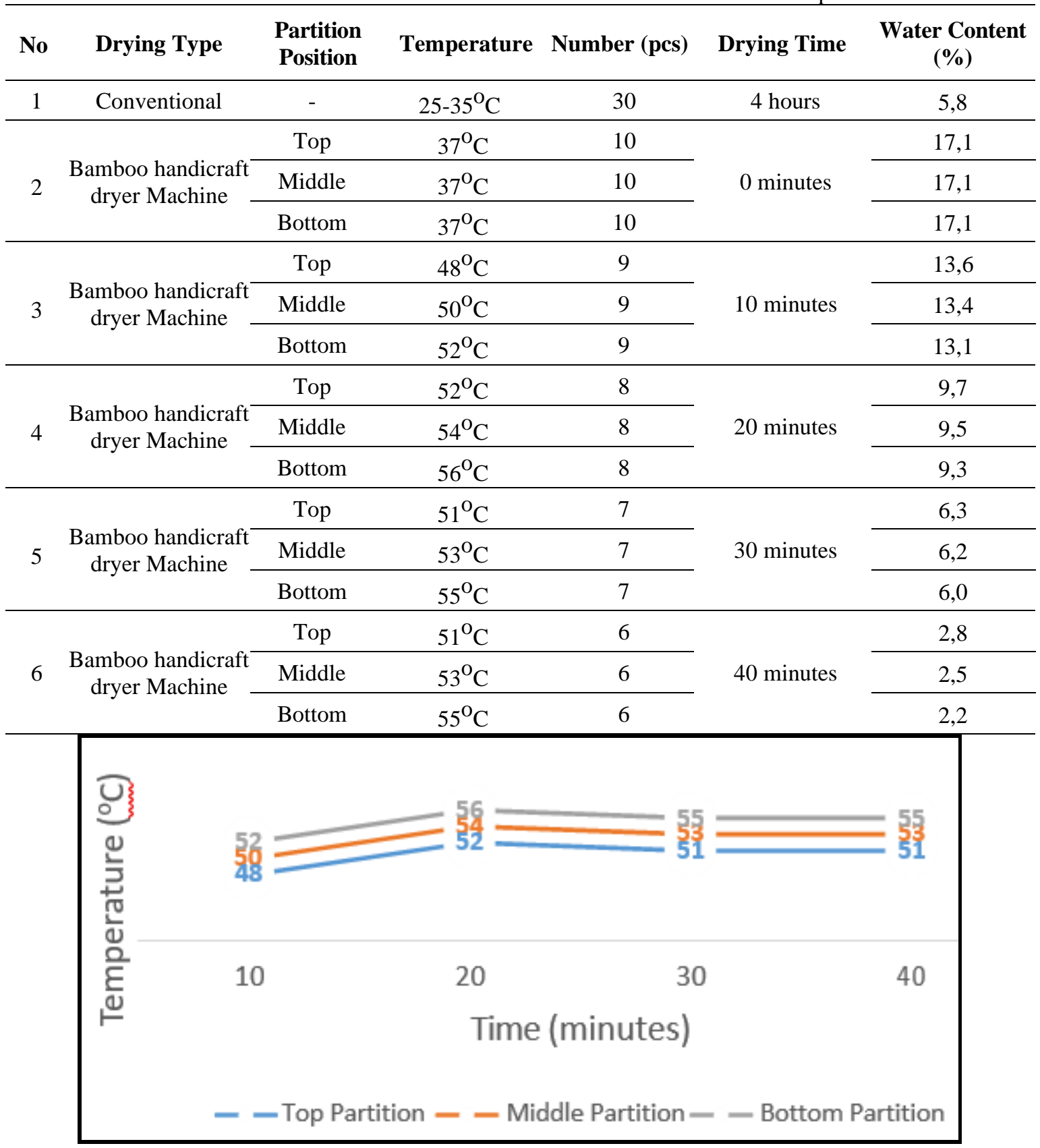

Fig. 8. Bamboo handicraft dryer Machine Temperature Chart

In Fig. 8, we can see that the bamboo. O handicraft dryer machine has consistency in heating. This stable temperature can accelerate the production of bamboo handicrafts to be dried.

\section{Conclusion}

The conclusion of this research is that the bamboo craft drying machine has several parts, including a blower, an air chimney, a drying room, LPG gas, and a stove room. In addition, based on the tests that have been carried out, the bamboo craft drying machine is very efficient because it can dry bamboo crafts to a water content of $2.5 \%$ only takes about 40 minutes, very efficient compared to conventional methods, which are only able to dry up to a water content of $58 \%$ with 4 hours drying time. The utilization of bamboo handicraft dryer machines can increase the productivity and quality of bamboo craftsmen's products in the Brajan area. 


\section{References}

[1] BPS, 2012. Penduduk Provinsi Daerah Istimewa Yogyakarta Hasil Sensus Penduduk 1961-2010. Yogyakarta: Badan Pusat Statistik (BPS).

[2] Abdullah, Kamaruddin. 2007. Solar PV Technology Applications in Indonesia:Teknologi Berbasis Sumber Energi Terbarukan Untuk Pertanian. Bogor: IPB Press.

[3] Kris, Jensen-Van Heste. 2009. What's the Difference Between Convection and Radiant Heat. Accessed from http://housewares.about.-com/Ir/heaters/335683/4/ on June 24, 2021, at $23.11 \mathrm{WIB}$.

[4] Muarif. 2013. Rancang Bangun Alat Pengering. Accessed from www.digilibspolsri.ac.id, on June 24, 2021, at 16.45 WIB.

[5] Dinata, Yuwono Marta. 2015. Arduino Itu Mudah. Jakarta : PT. Alex Media Komputindo.

[6] Radianto, Donny. 2012. Sensor Suhu Dengan LM 35. Accessed from http://teknologi.kompasiana.com/ on June 25, 2021, at 13.09 WIB.

[7] Sugiyono. 2016. Metode Penelitian Kuantitatif, Kualitatif dan R\&D. Bandung: PT Alfabeta. 